\title{
Pelagic Fish Behaviour During Trawl Sampling Off Angola
}

\author{
Eli Kyrkjebø Haugland and Ole Arve Misund
}

Institute of Marine Research, P.O. Box 1870, N-5817 Bergen, Norway

\begin{abstract}
Large sardinella (Sardinella maderensis and Sardinella aurita) in warm waters off the coast of Africa are known to be a challenge for pelagic trawl sampling, for example during acoustic surveys for abundance estimation. We observed the swimming behaviour of sardinella mixed with other pelagic species, mainly Cunene horse mackerel (Trachurus trecae), during sampling with a pelagic trawl in the course of a study of swimming behaviour and endurance in the trawl belly and escape behaviour during hauling. The study consisted of two pelagic trawl surveys with R/V "Dr. Fridtjof Nansen" off the coast of Angola. We observed the fish with a trawl sonde in the trawl mouth, from a towed vehicle with sonar and camera positioned above the trawl belly or the trawl mouth, and finally with a camera with video recorder in the trawl belly. The behaviour of the fish was quantified from the video recordings by observing the swimming speed of the fish relative to the trawl and by recording the frequency of different behaviours. Two different reactions of schools were observed. We defined a "fright" reaction as a sudden reaction, where individuals swam in different directions and the collective school organisation collapsed for a few seconds. The second type of school reaction, the "adjust" reaction, did not cause the school organisation to disintegrate, but caused the whole school to gradually change its swimming direction by moving closer to one of the sides or the bottom of the trawl. The fish were also observed to swim along within the trawl for tens of minutes, possibly for up to around an hour. The main conclusion of this study is that pelagic species in warm water have the potential to actively swim forward in the trawl and escape during hauling. This could have substantial consequences for trawl sampling during surveys in terms of species- and sizedependent selectivity.
\end{abstract}

Keywords: Pelagic trawling, sardinella, underwater video-recording, fish behaviour, fish escapes.

\section{INTRODUCTION}

Our knowledge of the behaviour of pelagic schooling fish during a trawl capture process is limited, although pelagic schooling marine fish of the family Clupeidae are among the most exploited species worldwide with a catch of around 16 mill ton annually [1]. Sardinella (Sardinella maderensis and Sardinella aurita) and horse mackerel (Trachurus trecae and Trachurus capensis) are the main pelagic stocks fished off Angola.

Pelagic schooling species are generally suitable for acoustic abundance estimation because their dense aggregations are reflected in strong acoustic recordings, and because these generally small pelagic species can usually be sampled fairly easily by pelagic trawl [2]. However, larger sardinella in warm waters off the African coast are known to be an exception, and escape by sardinella after they have entered the trawl has been documented [3].

Video recordings and photographic observations have earlier been used to study fish reactions to mobile fishing gear [4] as well as selectivity and escape from trawls $[5,6]$. Kim and Wardle [4] quantified fish (haddock, saithe, cod, mackerel and flatfish) reactions to towed fishing gears in the North Sea and classified them as either optomotor responses or erratic responses. They suggested that the kind of res-

*Address correspondence to this author at the Institute of Marine Research, P.O. Box 1870, NO-5817 Bergen, Norway; Fax: +47 552368 30;

E-mail: olem@imr.no ponses the fish displayed depend on sound impressions, light level, visibility, range and object contrast, combined with the physical ability of the fish to see, hear and move. Walsh and Godø [7] suggested that the size and number of fish and the flexible structure with unsteady geometry of the trawl gear also influenced responses to the fishing gear.

While sardinella are swimming inside the trawl they continuously need to adjust themselves to the moving trawl, their schooling mates and possible predators outside the trawl. In this study we observed the swimming behaviour and endurance of sardinella inside a pelagic trawl during trawling in situ, and we discuss the possibilities of escape behaviour during towing. Such knowledge is vital if we are to improve sampling strategies for pelagic species in warm waters.

\section{MATERIAL AND METHODS}

The behaviour of pelagic species inside a pelagic trawl was studied in two surveys. The catches consist of sardinella, mixed with mainly horse mackerel. Both surveys were performed by R/V "Dr. Fridtjof Nansen" off the coast of Angola, the first in May 1997 and the second in May 1998. An "A krehamn" pelagic trawl [8] with a vertical opening of about $15 \mathrm{~m}$ was used during both surveys and the trawl speed was around 4 knots. During hauling the speed was reduced to about 2 knots. The bottom depths ranged from 31 $\mathrm{m}$ to $80 \mathrm{~m}$ with a mode around $40 \mathrm{~m}$. The sea surface temperature varied between 20 and $23^{\circ} \mathrm{C}$ in both years. 


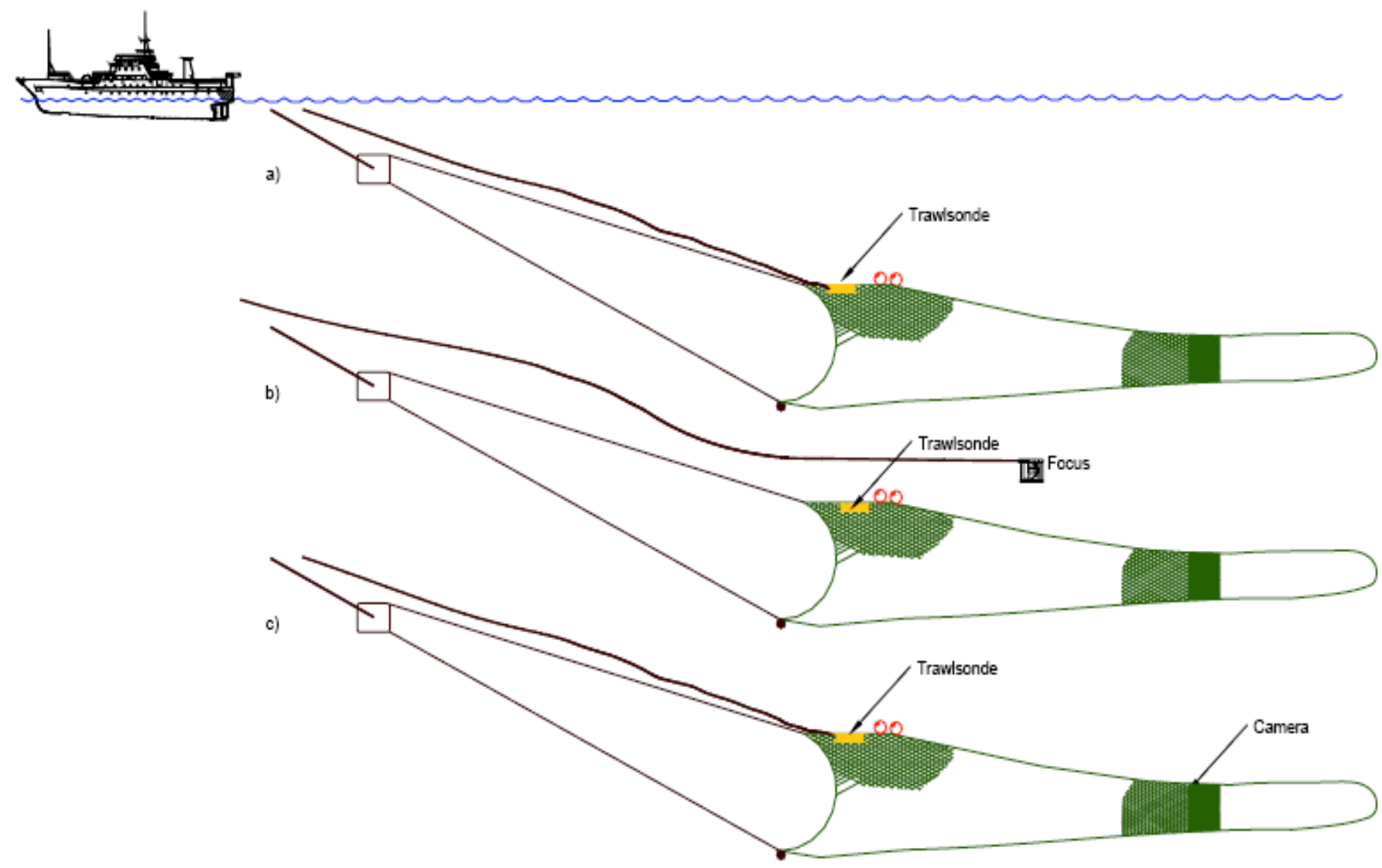

Fig. (1). The methodology employed in the three surveys included, a) a trawl-sonde with echogram printouts (Method A), b) a trawl-sonde and a towed platform equipped with a sonar and a camera (Method B), c) a trawl-sonde with echogram printouts in combination with a video-camera inside the trawl belly (Method C).

Three different methodologies as described below were employed; methods A and B in 1997 and method C in 1998 (Fig. 1).

\section{Method A: Cable Led Trawl-Sonde with Echogram Printouts}

This method was used for 10 trawl tows (Table 1) with durations of 20 to $121 \mathrm{~min}$, carried out in the light [5] or the dark [5]. A downwards-pointing trawl-sonde was installed in the upper trawl mouth and colour printouts from the echograms were kept for analysis. Visual observations for possible escapes of school during hauling were performed when light conditions permitted.

\section{Method B: Cable-Free Trawl-Sonde and a Towed Vehicle Equipped with a Sonar and Camera}

Seven tows (Table 2) with durations of 48 to $108 \mathrm{~min}$ were carried out with this set-up (one at dusk) immediately after the end of the trials with method A. A downwardspointing trawl-sonde was installed in the upper trawl mouth. Because a cable-free sonde was used, notes from the recordings were taken during the survey. In order to observe whether fish aggregated in the trawl belly after being recorded entering with the trawl sonde, we utilised a towed vehicle (Focus 400) equipped with a sonar and camera (Fig. 1). Behavioural observations from the Simrad Mesotech
FS3300 sonar and Silicon Integrated Tube (SIT) video camera were noted. The Focus 400 was deployed just after the trawl and raised from the sea just before the start of hauling and the vehicle was positioned between 1 and 3 metres above the net. The position of the Focus platform relative to the trawl varied between observing the trawl mouth or the trawl belly. The Focus platform could not be operated to record in the trawl mouth during hauling so observations of escaping fish were made either by the trawl sonde or by visual observations. Visual observations of possible escapes during hauling were made during all tows.

\section{Method C: Trawl-Sonde with Echogram Printouts and Video-Recording Inside the Trawl Belly}

In the final method, six tows (Table 3) with durations ranging from 35 to $99 \mathrm{~min}$ were performed, one of them at dusk. Once again, a downwards-pointing cabled trawl-sonde was installed in the upper trawl mouth and colour printouts from the echograms were kept for analysis. A cableless RS600 system, consisting of a tiltable SIT camera connected to a VHS HI8 video-recorder, was mounted in the upper trawl panel where the mesh size changed from 200 to 100 $\mathrm{mm}$. The camera frame was laced to the centre of the upper trawl panel, pointing downwards and slightly forwards inside the trawl, with the recorder housing just behind the camera (Fig. 1). The video recordings were made in natural daylight 
Table 1. Method A: Trawling with a Cable-Towed Trawl-Sonde with Echogram Printouts. The Entering and Escaping Times of Schools were found from the Echogram Printouts During 10 Tows off Angola in May in 1997. Duration is the total time the trawl was in the sea. The theoretical swimming time in the trawl is calculated. Five of the tens tows were carried out in the dark (PT1261, PT1268, PT1269, PT1272 and PT1276)

\begin{tabular}{|c|c|c|c|c|c|c|c|c|c|c|}
\hline & \multirow{2}{*}{$\begin{array}{c}\text { Time } \\
\text { (h:min) }\end{array}$} & \multirow{2}{*}{$\begin{array}{c}\text { Duration } \\
(\min ) \\
\end{array}$} & \multirow{2}{*}{$\begin{array}{l}\text { Speed } \\
\text { (knots) }\end{array}$} & \multirow{2}{*}{$\begin{array}{c}\text { Catch }(\mathrm{kg}) \\
\text { total/sardinella }\end{array}$} & \multicolumn{4}{|c|}{ Entering (min after start) } & \multirow{2}{*}{$\begin{array}{c}\text { Escaping time } \\
\text { (min after start) }\end{array}$} & \multirow{2}{*}{$\begin{array}{c}\text { Swimming in } \\
\text { trawl (min) }\end{array}$} \\
\hline & & & & & a & $\mathbf{b}$ & c & d & & \\
\hline PT1261 & $06: 19$ & 59 & 3,8 & $19 / 13$ & $3-10$ & $18-26$ & $41-43$ & 45 & $53-54$ & $\min 7, \max 49$ \\
\hline PT1267** & $13: 40$ & 92 & 3,9 & $16 / 0$ & 9 & 17 & $44-46$ & $68-71^{*}$ & $83 * *$ & $\min 12, \max 74$ \\
\hline PT1268 & $17: 30$ & 40 & 4,2 & $1954 / 1425$ & $10-11$ & $13-16$ & $23-28$ & $31-32$ & & \\
\hline PT1269 & $19: 56$ & 20 & 3,9 & $1217 / 395$ & $3-4$ & 7 & $10-13$ & & 16 & $\min 3, \max 13$ \\
\hline PT1271 & $15: 12$ & 67 & 4,1 & $0 / 0$ & & & & & & \\
\hline PT1272 & 19:18 & 20 & 3,6 & $23817 / 11052$ & $12-13$ & & & & & \\
\hline PT1273*^ & $07: 35$ & 61 & 4,2 & $75 / 71$ & $31-32$ & $38-39$ & $42-45$ & $48-50$ & $55^{* \wedge}$ & $\min 5, \max 25$ \\
\hline PT1274 & $12: 08$ & 121 & 4,5 & $128 / 81$ & $20-22$ & $48-49$ & & & & \\
\hline
\end{tabular}

* Two schools close together

** Visual observation of escape during towing back

*^ Several large schools were entering. Escaping was not observed due to noise on the echogram but was indicated due to the small catch.

Table 2. Method B: Trawling with a Cable-Less Trawl-Sonde and a Towed Vehicle with Sonar and Camera. This part consist of seven tows off Angola in May 1997. A towed vehicle (Focus) equipped with a sonar FS3300 and camera alternated between recording above the trawl mouth (entering) and the trawl belly. A cable-less trawl-sonde recorded fish in the trawl mouth. Duration is the total time the trawl was in the sea. The theoretical swimming time in the trawl is calculated

\begin{tabular}{|c|c|c|c|c|c|c|c|c|c|c|c|}
\hline & \multirow{2}{*}{$\begin{array}{c}\text { Time } \\
\text { (h:min) }\end{array}$} & \multirow{2}{*}{$\begin{array}{c}\text { Duration } \\
(\min )\end{array}$} & \multirow{2}{*}{$\begin{array}{l}\text { Speed } \\
\text { (knots) }\end{array}$} & \multirow{2}{*}{$\begin{array}{c}\text { Catch (kg) } \\
\text { total/sardinella }\end{array}$} & \multicolumn{3}{|c|}{ Entering (min after start): } & \multicolumn{2}{|c|}{$\frac{\text { Trawl-belly obs }}{\text { (min after start): }}$} & \multirow{2}{*}{$\begin{array}{c}\begin{array}{c}\text { Escaping } \\
\text { time }\end{array} \\
\begin{array}{c}\text { (min after } \\
\text { start) }\end{array}\end{array}$} & \multirow{2}{*}{$\begin{array}{c}\begin{array}{c}\text { Swimming } \\
\text { in }\end{array} \\
\text { trawl (min) }\end{array}$} \\
\hline & & & & & Sonde & FS3300 & Camera & FS3300 & Camera & & \\
\hline PT1277* & 09:00 & 106 & 3,8 & $200 / 200$ & & & & & & & $55^{*}$ \\
\hline PT1278** & $16: 09$ & 76 & 3,6 & $84 / 63$ & & $\begin{array}{c}29 \\
40 \\
47 \\
58 * *\end{array}$ & & & & & \\
\hline PT1279 & 09:06 & 92 & 4,2 & $5770 / 5269$ & $\begin{array}{l}19 \\
36\end{array}$ & 18 & & $24-36$ & $\begin{array}{l}28 \\
31 \\
36\end{array}$ & & $\begin{array}{c}\min 0, \max \\
17\end{array}$ \\
\hline PT1280 & $12: 43$ & 86 & 3,7 & $4976 / 4636$ & $\begin{array}{l}19 \\
27 \\
31 \\
45\end{array}$ & & 35 & 29 & $\begin{array}{c}8 \\
29 \\
35 \\
49\end{array}$ & & $\begin{array}{c}\min 0, \max \\
30\end{array}$ \\
\hline PT1282 & $12: 58$ & 98 & 2,7 & $268 / 129$ & 2 & & & $\begin{array}{l}12 \\
13 \\
25\end{array}$ & $\begin{array}{l}32 \\
39 \\
51\end{array}$ & & $\begin{array}{c}\min 10, \max \\
49\end{array}$ \\
\hline PT1283 & $08: 37$ & 48 & 3,0 & $279 / 8$ & 13 & & & & & & \\
\hline PT1285*^ & $12: 08$ & 108 & 3,2 & $224 / 118$ & $\begin{array}{c}57 \\
64-67 \\
92-96\end{array}$ & & & 72 & & $106^{* \wedge}$ & $\begin{array}{c}\min 10, \max \\
49\end{array}$ \\
\hline
\end{tabular}

* The school swam at the same speed as the trawl for 55 min according to the cruise diary.

** Observations of later entering schools impossible due to reduced light level.

*^ Escaping recorded by the trawl-sonde in addition to visual observation of escaping during towing back. 
Table 3. Method C: Trawling with a Cable-Towed Trawl-Sonde with Echogram Printouts and Video-Recording. Analysis of Fish Behaviour from Echograms Recorded by the Trawl-Sonde and from Underwater Video-Recordings of Sardinella During the Survey off Angola in May 1998. "AR"=Adjust Reaction, "FR"=Fright Reaction. Duration is the total time the trawl was in the sea. The theoretical swimming time in the trawl is calculated

\begin{tabular}{|c|c|c|c|c|c|c|c|c|c|c|c|c|}
\hline & Time & Duration & Speed & Catch (kg) & \multicolumn{4}{|c|}{ Entering (min after start) } & \multirow{2}{*}{$\begin{array}{c}\begin{array}{c}\text { Escaping } \\
\text { time }\end{array} \\
\begin{array}{c}\text { (min after } \\
\text { start) }\end{array}\end{array}$} & \multirow{2}{*}{$\begin{array}{l}\text { Swimming in } \\
\text { trawl (min) }\end{array}$} & \multicolumn{2}{|c|}{$\begin{array}{l}\text { Numb. of } \\
\text { reactions }\end{array}$} \\
\hline & (h:min) & $(\min )$ & (knots) & total/sardinella & $\mathbf{a}$ & $\mathbf{b}$ & c & d & & & adjust & fright \\
\hline РТ2496 & $12: 14$ & 49 & 4.0 & $34 / 14$ & 18 & & & & & & 1 & 3 \\
\hline PT2497* & $15: 10$ & 61 & 4.1 & $493 / 454$ & $5-7$ & $9-10$ & $12-18$ & $46-56$ & & & 12 & 11 \\
\hline PT2500** & $16: 56$ & 35 & 4.0 & $665 / 365$ & & & & & & & $(0)$ & (2) \\
\hline PT2501*^ & $07: 24$ & 99 & 4.0 & $25 / 14$ & 17 & 43 & 66 & & $84 * \wedge$ & $\min 18, \max 67$ & 12 & 5 \\
\hline PT2502*^ & $15: 56$ & 67 & 4.0 & $45 / 11$ & 1 & 54 & & & $62 * \wedge$ & $\min 8, \max 61$ & & \\
\hline РT2504 & $16: 07$ & 55 & 4.0 & $722 / 677$ & 15 & $47-53$ & & & & & 0 & 10 \\
\hline
\end{tabular}

* Seal observations outside the trawl.

** No echogram printout from the trawl-sonde. Onset of dusk prevented behavioural observations.

*^ Visual observation of escaping fish during towing back.

and kept for analysis. Visual observations of escapes during hauling were performed during all tows.

\section{BEHAVIOURAL OBSERVATIONS}

\section{Swimming Time Inside the Trawl before Possible Escape}

The echograms showed when the fish entered the trawl and whether they formed a continuous school/layer or several schools/bunches. Fish swimming out of the trawl mouth during towing could be observed on some of the echograms, but at the very end of the tows the propeller wake during hauling often prevented fish from being registered. The exact time was not automatically printed on the echograms, so manual indications were inserted to estimate the times of entrance/escape. The time from the first and last entrances on the echogram to the time of escape during hauling (from the echograms or by visual observation) was estimated, giving theoretical maximum and minimum swimming times in the trawl. This was done for methods A and C (Fig. 1).

In method $\mathrm{B}$, observations of fish entering the trawl mouth and later observations inside the trawl belly (via the equipment on the Focus platform) provided information about swimming times inside the trawl during three tows.

Visibility in the sea varied between the tows with recordings (method C), mainly due to diel light variation and turbidity. The visibility of fish on the videotapes varied from about 5 to $7 \mathrm{~m}$. Depending on the light conditions, turbidity and the position and tilt of the observation window of the video camera, it was sometimes also possible to see the bottom or side panels of the trawl. The time from when the trawl entered the sea until it was completely open was noted, as were the times at which the fish were observed, occurrences of various behavioural reactions and unusual events (observations of predators outside the trawl, shaking of the trawl etc.), in addition to when the trawl net started to close during hauling and when the trawl left the sea.

\section{Swimming Specifications}

The number of fish observed on the videos was assigned to one of three categories: no fish, separate individual fish or a school (fish behaving collectively). The swimming speed of the fish was categorized according to movement relative to the trawl net:

- Follow: the fish keep station with the trawl net and maintain the same speed as the trawl.

- $\quad$ Swimming forwards: the fish swim forward relative to the trawl net and faster than the trawling speed.

- $\quad$ Gliding backwards: the fish glide backwards relative to the trawl net and swam slower than the trawl, while still heading and swimming forwards.

\section{School Behaviour}

Collective school reactions were observed on several occasions. Depending on the intensity and type of reactions, the behaviours were classified into two categories:

- $\quad$ Adjust Reactions: did not led to a sudden disintergration of the school organisation but caused the whole school to gradually change swimming direction and move closer to one side or the bottom of the trawl.

- Fright Reactions: were characterised by a sudden simultaneous mass reaction, with individual fish swimming in different directions and the collective school organisation collapsing for a few seconds.

The occurrences of the two behavioural categories in addition to the occurrence of "forward swimming" and "backward gliding" were tabulated for analysis. By standardizing the time of occurrence of the observations to a scale from 0 to 100 , the relative time of occurrences during the tows could be plotted.

\section{Tail-Beat Frequencies}

The tail-beat frequency was counted to estimate the number of tail beats per second and per metre, based on a swimming speed of approximately $2 \mathrm{~m} \mathrm{~s}^{-1}$ (4 knots) for fish keeping place with the trawl. A tail beat was defined from the tail being at a given start point at one side of the fish and returning to the same position. By playing the videotapes in 
slow motion, at one fifth of actual speed, the tail beats could be counted. During playback the tail beats were counted for one fish for 10 to $40 \mathrm{~s}$. Tows PT2497 and PT2504, in which sardinella made up 92 to $94 \%$ of the total catch, were chosen for counting.

\section{RESULTS}

The catch mainly comprised sardinella mixed with Cunene horse mackerel. In 13 of the 23 tows sardinella accounted for more than $50 \%$ of the catch (Tables 1, 2 and $3)$. In three of the 23 tows there was no catch of sardinella or no catch at all. Because the study in fact copes with escapes of fast-swimming species like sardinella, all the tows above are included in the study.

\section{Swimming Times Inside the Trawl before Possible Escape}

Schools entering the trawl were recorded on the echograms in 19 of the 23 tows (Fig. 2, Tables 1, 2 and 3). In method B (towed vehicle equipped with sonar and camera) fish entering were recorded by the sonar in two of the tows and in one tow by the camera (Table 2). Fish inside the trawl belly during method $\mathrm{B}$ were observed on four occasions by the sonar and three times by the camera (Table 2). During the whole study schools were seen to escape on five occasions. Escaping schools were recorded on the echograms three times. Swimming time in the trawl before possible escapes was calculated in tow PT1273, although no recording or visual observation of an escape was made. This could be done because of the small catch, in spite of the fact that several large schools were observed entering.

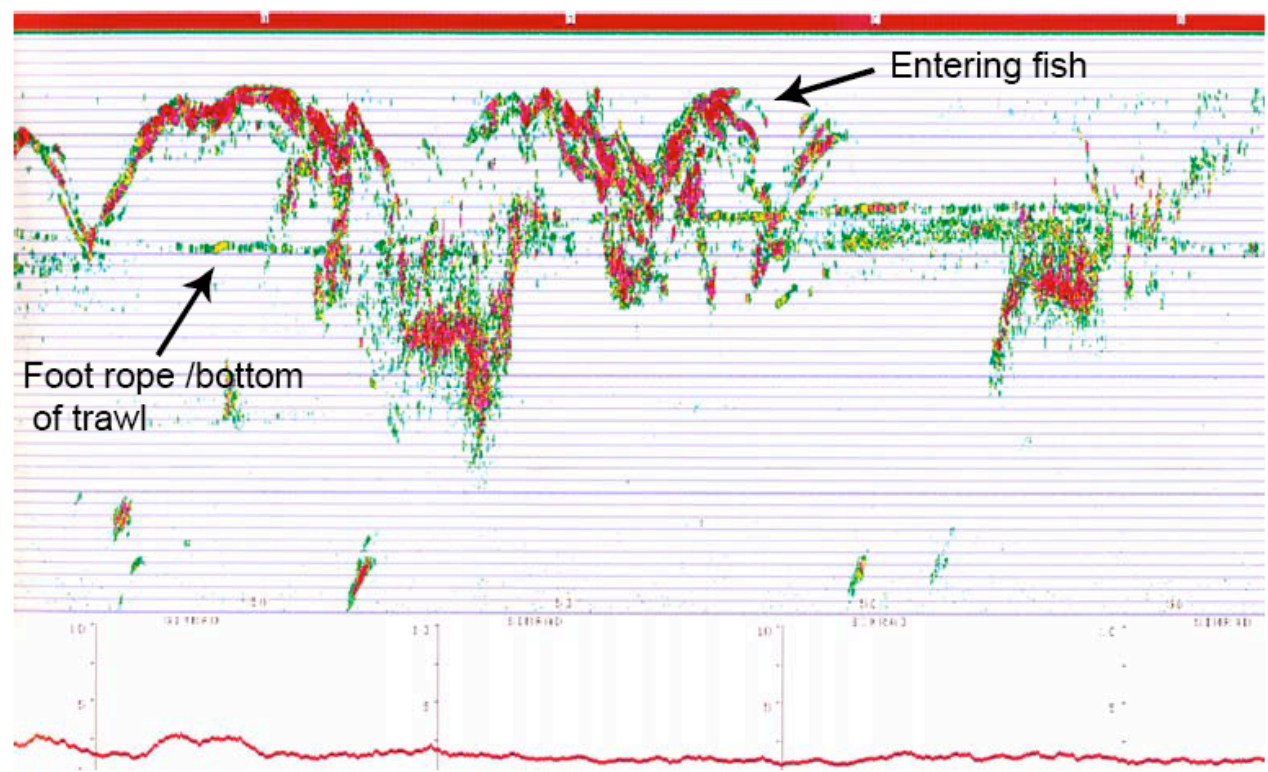

Fig. (2). Echogram from the trawl sonde taken from tow PT1261 in 1997, method A. The echogram shows fish entering the trawl. The continuous line just above the middle of the picture represents echoes from the foot-rope/bottom of the trawl. Some fish are passing under the foot-rope.

a)

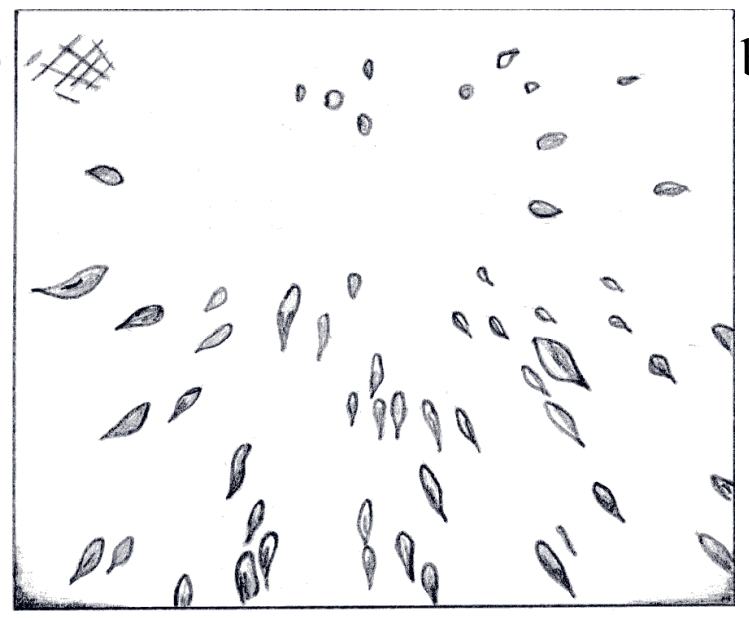

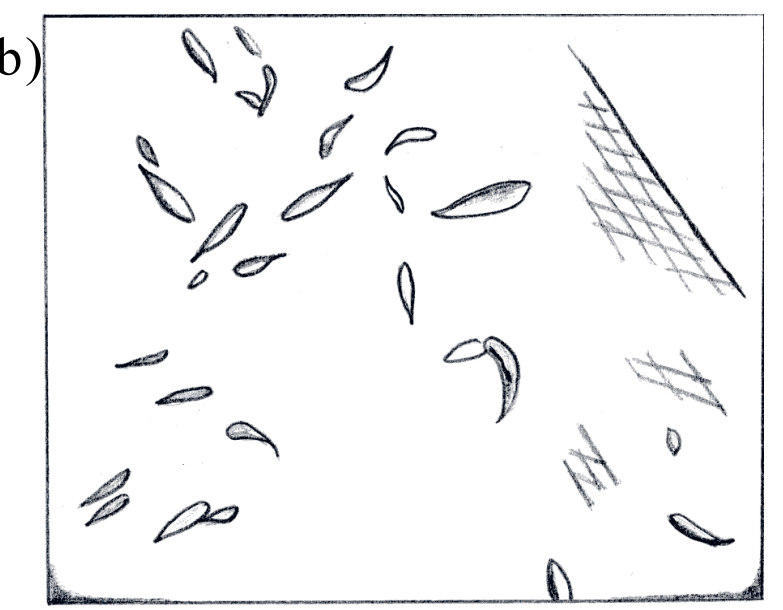

Fig. (3). Drawing of a still image from the video-recordings of sardinella schools when a) swimming forwards inside the trawl and b) showing a sudden fright reaction. 
On the basis of the above observations, schools were estimated to swim along with the trawl for tens of minutes and possibly up to about an hour before escaping, provided that it was among the first schools recorded to enter (Tables $1,2$ and 3$)$.

\section{Swimming Specifications}

Most of the time, the fish maintained the same speed as the trawl. On 21 occasions, schools were observed swimming forward (Fig. 3). Forward swimming seemed to be associated with fright reactions. Sixty-seven per cent of the forward swimming observations were made at the start of or during hauling (Fig. 4). Fish gliding backwards relative to the trawl were observed on only four occasions and general trends can thus not be predicted (Fig. 4). Except during short sequences occurring during the fright reactions, the fish were never observed swimming against the towing direction, towards the codend. During the very last part of the hauling phase, when the trawl closed up, the fish could no longer be observed, due to either escapes or the capture process.

\section{School Reactions}

School reactions were observed during five of the six video-recorded trawl tows (method C, Table 3). A total of 25 adjust reactions were observed in three tows. In one of these only one adjust reaction was observed, while in the other two tows 12 adjust reactions were observed per tow (Table 3). Only four of the adjust reactions occurred after the trawl had started to close. Fright reactions (Fig. 4) were observed during the different trawling phases, but $58 \%$ of the observations occurred after the trawl had started to close (Fig. 4).

\section{Tail-Beat Frequencies}

For long periods of time, schools maintained their positions inside the trawl during towing at around $2 \mathrm{~m} \mathrm{~s}^{-1}$ (4 knots). Individual fish could be followed for up to a maximum of about $40 \mathrm{~s}$ at a time, after which movement associated with the school dynamics made this impossible. The tail-beat frequency was $8.5 \pm 0.6$ beats $\mathrm{s}^{-1}$ in PT2497 $(n=33)$ and $8.7 \pm 1.0$ beats $\mathrm{s}^{-1}$ in PT2504 $(\mathrm{n}=28)$. When sardinella swam at a speed of $2.04 \mathrm{~m} \mathrm{~s}^{-1}$ (4 knots), this is equivalent to 4.2 or 4.3 tails beats to move one metre.

\section{Seal Observation}

A seal was observed to slowly pass outside the trawl on five of the eight occasions on which adjust reactions occurred and sections of the trawl panel were visible (in tow PT2497). In the middle of the tow the camera tilted away from the trawl panel and observations outside the trawl was no longer possible.

\section{DISCUSSION}

Sardinella is known to be difficult to catch representatively by pelagic trawls [3]. We found that sardinella mixed mainly with horse mackerel in a pelagic trawl belly swam in the towing direction, maintaining the same speed as the trawl of $2 \mathrm{~m} \mathrm{~s}^{-1}$ for tens of minutes, possibly for as much as around an hour.

From the underwater video observations we observed two types of collective school behaviours; adjust reactions and fright reactions. Adjust reactions did not cause the

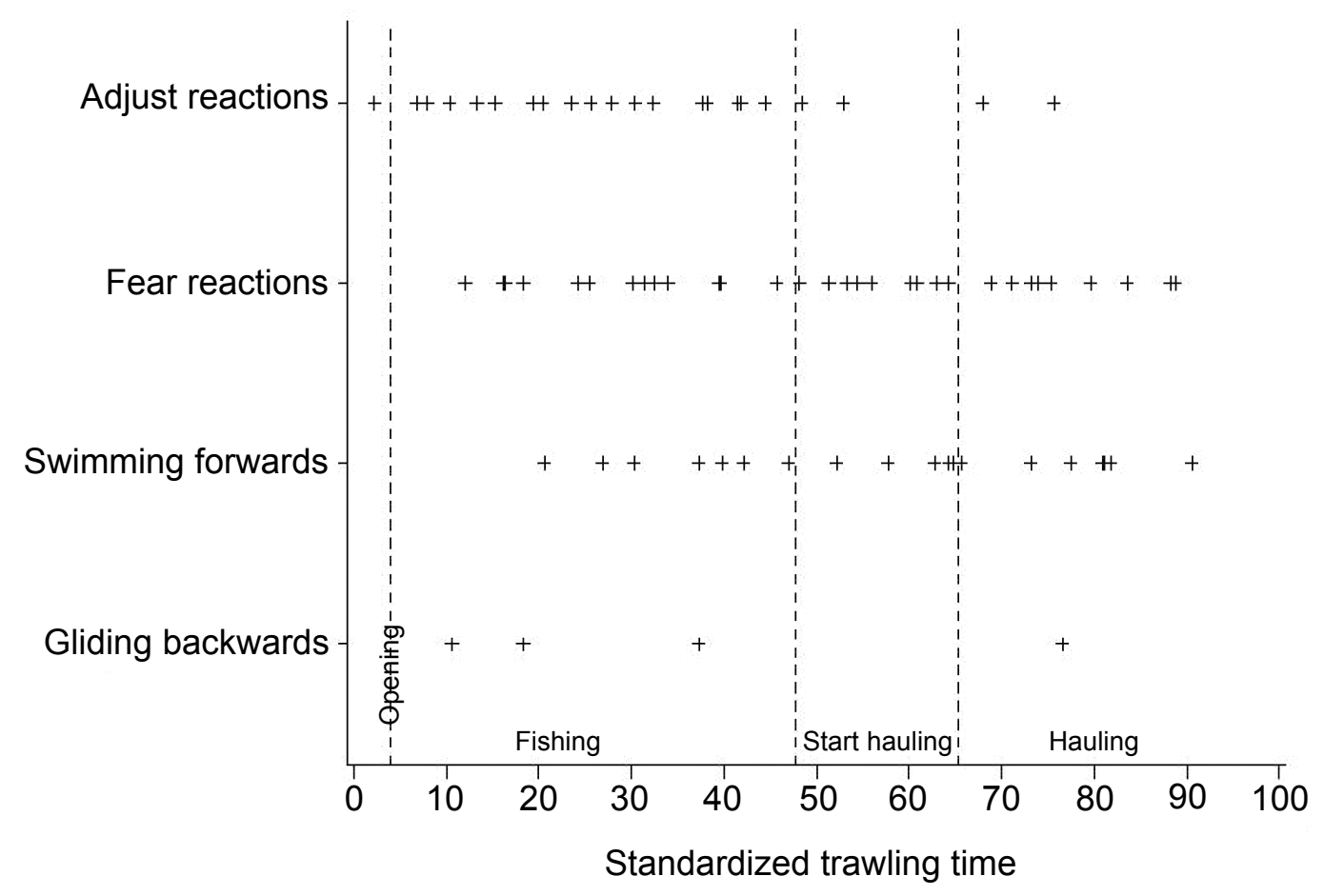

Fig. (4). Behavioural reactions observed from the underwater video-recording during trawling. The six tows are plotted together. The total trawling times have been transformed to a standardized time-scale, showing the times of occurrence of the various behaviours. The three dotted lines indicate the time periods during the trawling:- "0-4": the time until opening of the trawl, "48-65": the trawl starts closing together during towing and "65-onwards": trawl hauling and closing. 
school organisation to disintegrate, but resulted in a collective change during which the whole school gradually changed swimming direction and moved closer to one side or the bottom of the trawl. The video-recordings show that such reactions spread from the individuals in the part of the school that reacted to the rest of the school. This caused the whole school to display a collective reaction, when e.g. a predator (seal) was observed outside the trawl by the individuals closest to it (tow PT2497). Such an adjust reaction might be comparable to the "waves of agitation" recorded by sonar in anchovy (Engraulis ringens) schools [9]. Gerlotto et al., [9] interpreted the "waves of agitation" as a way of transmitting information in response to a predator. By means of a simulation, Huse et al., [10] showed that the reaction of only a small proportion of a school (at least 7\%) may cause the whole school to change direction. It is presumably adaptive for individuals to stay in and react with the rest of the school in the natural environment, especially for antipredator behaviour [11].

Fright reactions generally occurred later in the trawling sequences than adjust reactions. Fright reactions were characterised by a sudden simultaneous mass movement, with individual fish swimming in different directions and the collective school organisation collapsing for a few seconds. Walsh and Godø [7] suggested that the number of fish and flexible structure with unsteady geometry of the trawl gear influenced the fishes' responses to the fishing gear. During hauling, movements of the trawl gear could provoke fright reactions. Furthermore, most of the fright reactions were observed in the two tows (PT2497 and PT2504) with high catches (method C). High fish densities in the trawl belly could increase the contact with the trawl net that could provoke reactions in fishes [7]. Kim and Wardle [4] described two different types of behaviour in the trawl. The optomotor response is described by steady position-holding, characterized by low and regular variations in swimming speed, acceleration and angular velocity, while the erratic response caused a change in position by large variation in speed, acceleration and angular velocity. The fright reaction might be categorized as an erratic response.

The swimming speed and endurance of sardinella has not, to our knowledge, been measured in laboratory studies. In situ sardinella schools have been found to swim at a speed of $1.24 \mathrm{~m} \mathrm{~s}^{-1}$ off the coast of Angola (May and July; [12]). Comparably, the mean swimming speed of herring during migration has been observed to be $1.45 \mathrm{~m} \mathrm{~s}^{-1}$ [13]. For anchovy schools off Peru, Gerlotto et al., [9] recorded a speed of $0.3 \mathrm{~m} \mathrm{~s}^{-1}$. These differences in reported swimming speed can not be directly compared due to differences in behaviour and abiotic factors between the surveys, but they do indicate known species-specific swimming speeds [14].

Accurately extracting the maximum swimming endurance of sardinella schools in a pelagic trawl is difficult, due to several schools entering at different times, and variable towing times. The maximum swimming time of $13 \mathrm{~min}$ (PT1269 and PT1276) does not necessary mean that this was the maximum duration of time the fish was capable of following the trawl, because these tows were only $20 \mathrm{~min}$ long. In PT1273 the first entry was after $31 \mathrm{~min}$, showing that late entering also restricts our ability to postulate swimming capacity. Maximum sustained swimming speed is defined as the maximum speed that does not lead to exhaustion and should last for minimum $200 \mathrm{~min}$ [14]. Further, prolonged swimming speed is defined as lasting from a few seconds up to $200 \mathrm{~min}$ and leading to exhaustion; the higher the speed, the shorter the endurance [14]. For herring the maximum sustained swimming speed has been found to be $1.06 \mathrm{~m} \mathrm{~s}^{-1}$ (size of $0.25 \mathrm{~m}$ at $13.5^{\circ} \mathrm{C},[15]$ ). $\mathrm{We}$ found that sardinella could probably maintain a speed of about $2 \mathrm{~m} \mathrm{~s}^{-1}$ swimming inside a pelagic trawl for up to about an hour. Categorizing sardinella swimming speed in terms of the definitions of $\mathrm{He}$ [14] is problematic, due to the lack of observations of exhaustion, and because the minimum time of $200 \mathrm{~min}$ (needed for classification as maximum sustainable swimming speed) was never observed.

Species-specific swimming characteristics are also related to abiotic factors such as light level and water temperature $[14,16]$. With reduced light intensity fish find it difficult to position themselves relative to each other and to the trawl net [4]. Olla et al., [17] observed walleye pollock (Theragra chalcogramma) during trawling under light and dark conditions, and found that the structured swimming observed during light conditions changed in the dark, with little or no active swimming, reduced orientation and rapid backward gliding in the trawl. Similarly, Glass and Wardle [18] found that "the ordered pattern of reaction behaviour to an approaching net" ceased in haddock (Melanogrammus aeglefinus) being trawled at 3 knots at low light levels $\left(<10^{-6}\right.$ lux). In our study, reduced light may also have reduced swimming orientation in a trawl and increased catch-rate. But due to limited data and the lack of accurate light measurements, this is only an indication. However, all the four tows with high catches in method A were performed in the dark. The pelagic species in our study were observed in high sea temperatures of around 20 to $23^{\circ} \mathrm{C}$. Water temperature is an abiotic factor that influences swimming performance [14]. Generally speaking, higher water temperatures allow higher swimming speed and endurance [14] and probably increase the ability of fish to avoid the trawl mouth area or to keep station within the trawl.

Several pelagic species have been observed to avoid towed gear, among them herring and sprat (Sprattus sprattus) [19] and mackerel (Scomber scombrus, 20). Slotte et al., [20] documented a size-specific difference in mackerel catches from the same area between scientific trawl samples and commercial purse seine catches. Age, length and weight were significantly lower in the scientific trawl samples than in the purse-seine catches. Suuronen et al., [21] found by video recordings that Baltic herring apparently tried to maintain their position in relation to a midwater trawl (trawling at 3 knots), but that they continuously lost ground and ended up in the codend. Only some of the largest individuals made brief forward-swimming bursts, while a few smaller individuals escaped trough the meshes in the upper trawl belly, especially in darkness, due to poorer orientation to the trawl net. Suuronen et al., [21] conclude that herring that escaped were significantly smaller than those caught in the cod end and that the majority of the fish in the trawl path were caught. These examples demonstrate the importance of being aware of size selection during trawl sampling. 
In conclusion, sardinella mixed with horse mackerel were found to be fast-swimming fish that seem to be capable of maintaining a speed of $2 \mathrm{~m} \mathrm{~s}^{-1}$ for tens of minutes, perhaps for more than an hour. At a speed of $2 \mathrm{~m} \mathrm{~s}^{-1}$ sardinella need 4.2 or 4.3 tail beats per second to move one metre. At this speed sardinella have a unique potential to avoid entering the trawl, but it also has the ability to keep swimming in the trawl belly and possibly to escape later from the trawl mouth during hauling. Differences in swimming capacity between species and size groups have consequences for catchability during trawl sampling during scientific surveys. If a high proportion of a fast-swimming species such as sardinella, especially large individuals, escape from the trawl, the species and size distribution in the trawl samples will not be representative of the true distribution. Especially after fish have entered the trawl, speed and duration appear to be key factors in reducing selection effects when fast-swimming pelagic species are being sampled.

\section{ACKNOWLEDGEMENTS}

We are grateful to Svein Løkkeborg and Aud Vold Soldal for improving the manuscript.

\section{CONFLICT OF INTEREST}

None declared.

\section{REFERENCES}

[1] FAO, 2004. The state of World Fisheries and Aquaculture, 2004. http://www.fao.org/documents/show_cdr.asp?url_file=/DOCREP/0 07/y5600e/y5600e00.htm

[2] Røttingen I, Tjelmeland S. Evaluation of the absolute levels of acoustic estimates of the 1983 year class of Norwegian spring spawning herring. ICES J Mar Sci 2003; 3: 480-5.

[3] Misund OA, Luyeye J, Coetzee J, Boyer D. Trawl sampling of small pelagic fish off Angola: effects of avoidance, towing speed, tow duration, and time of day. ICES J Mar Science 1999; 56: 27583.

[4] Kim YH, Wardle CS. Optomotor response and erratic response: quantitative analysis of fish reaction to towed fishing gears. Fisheries Res 2003; 60: 455-70.

[5] Dremière P-Y, Fiorentini L, Cosimi G, Leonori I, Sala A, Spagnolo A. Escapement from the main body of the bottom trawl used for the Mediterranean international trawl survey (MEDITS). Aqua Living Res 1999; 12(3):207-17.
[6] Weinberg KL, Munro PT. The effect of artificial light on escapement beneath a survey trawl. ICES J Mar Sci 1999; 56: 26674.

[7] Walsh SJ, Godø OR. Letter to the Editor. Quantitative analysis of fish reaction to towed fishing gears - What responses are important? Fish Res 2003; 63: 289-92.

[8] Valdemarsen JW, Misund OA. Trawl design and techniques used by Norwegian research vessels to sample fish in the pelagic zone. In: Precision and relevance of pre-recruit studies for fishery management related to fish stocks in the Barents Sea and adjacent waters. ICES J Mar Science 1995; pp. 135-44.

[9] Gerlotto F, Bertrand S, Bez N, Gutierrez M. Waves of agitation inside anchovy schools observed with multibeam sonar: a way to transmit information in response to predation. ICES J Marine Sci 2006; 63: 1405-17.

[10] Huse G, Railsback S, Fernö A. Modelling changes in migration pattern of herring: collective behaviour and numerical domination. J Fish Biol 2002; 60: 571-82.

[11] Nøttestad L, Fernø A, Mackinson S, Pitcher T, Misund OA. How whales influence herring school dynamics in a cold-front area of the Norwegian Sea. ICES J Marine Sci 2002; 59: 393-400.

[12] Misund OA, Luyeye J, Boyer D, et al. Observations on the nearsurface behaviour of sardinella schools in Angolan waters. Afr J Marine Sci 2005; 27(1): 169-76.

[13] Nøttestad L, Aksland M, Beltestad A, Fernø A, Johanessen A Misund OA. Schooling dynamics of Norwegian spring spawning herring (Clupea harengus L.) in coastal spawning area. Sarsia 1996; 80: $277-84$.

[14] He P. Swimming performance of marine fish in relation to fishing gears. In: Wardle CS, Hollingworth, CE, Eds. Fish Behaviour in Relation to Fishing Operations. ICES Mar Sci Sympose 1993; 196: 183-9.

[15] He P, Wardle CS. Endurance at intermediate swimming speeds pf Atlantic mackerel, Scomber scombrus, L., herring, Clupea harengus L and saithe, Pollachius virens L. J Fish Biol 1988; 33: 255-66.

[16] Kim YH, Wardle CS. Modelling of swimming ability limits for marine fish. J Korean Fisheries Soc 1997; 30(6): 929-35.

[17] Olla BL, Davis MW, Rose C. Differences in orientation and swimming of walleye pollock Theragra chalcogramma in a trawl net under light and dark conditions: concordance between field and laboratory observations. Short communications. Fish Res 2000; 44: 261-6.

[18] Glass CW, Wardle CS. Comparison of the reactions of fish to a trawl gear, at high and low light intensities. Fish Res 1989; 7: 24966.

[19] Misund OA, Aglen A. Swimming behaviour of fish schools in the North Sea during acoustic surveying and pelagic trawl sampling. ICES J Mar Sci 1992; 49: 325-34

[20] Slotte A, Skagen D, Iversen SA. Size of mackerel in research vessel trawls and commercial purse-seine catches: implications for acoustic estimation of biomass. ICES J Mar Sci 2007, 64: 989-94.

[21] Suuronen P, Lehtonen E, Wallace J. Avoidance and escape behaviour by herring encountering midwater trawls. Fish Res 1997; 29: $13-24$. 